US Army Corps of Engineers
US-CE-CProperty of the

United States Government

MISCELLANEOUS PAPER GL-88-30

\title{
SUBSTANDARD MATERIALS FOR PAVEMENT CONSTRUCTION
}

\author{
by
}

Raymond S. Rollings

Geotechnical Laboratory

DEPARTMENT OF THE ARMY

Waterways Experiment Station, Corps of Engineers

PO Box 631, Vicksburg, Mississippi 39181-0631

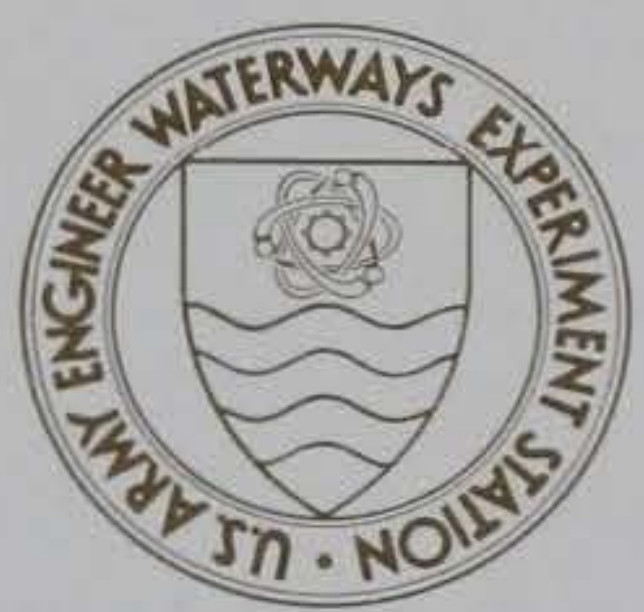

September 1988

Final Report

Approved For Public Release; Distribution Unlimited

\section{Library Branch}

Technical Information Center

U.S. Army Engineer Waterways Experiment Station Vicksburg, Mississippi

\author{
Prepared for DEPARTMENT OF THE ARMY \\ US Army Corps of Engineers \\ Washington, DC 20314-1000 \\ Under Project AT40, Task CO \\ Work Unit 541
}


Unclassified

SECURITY CLASSIFICATION OF THIS PAGE

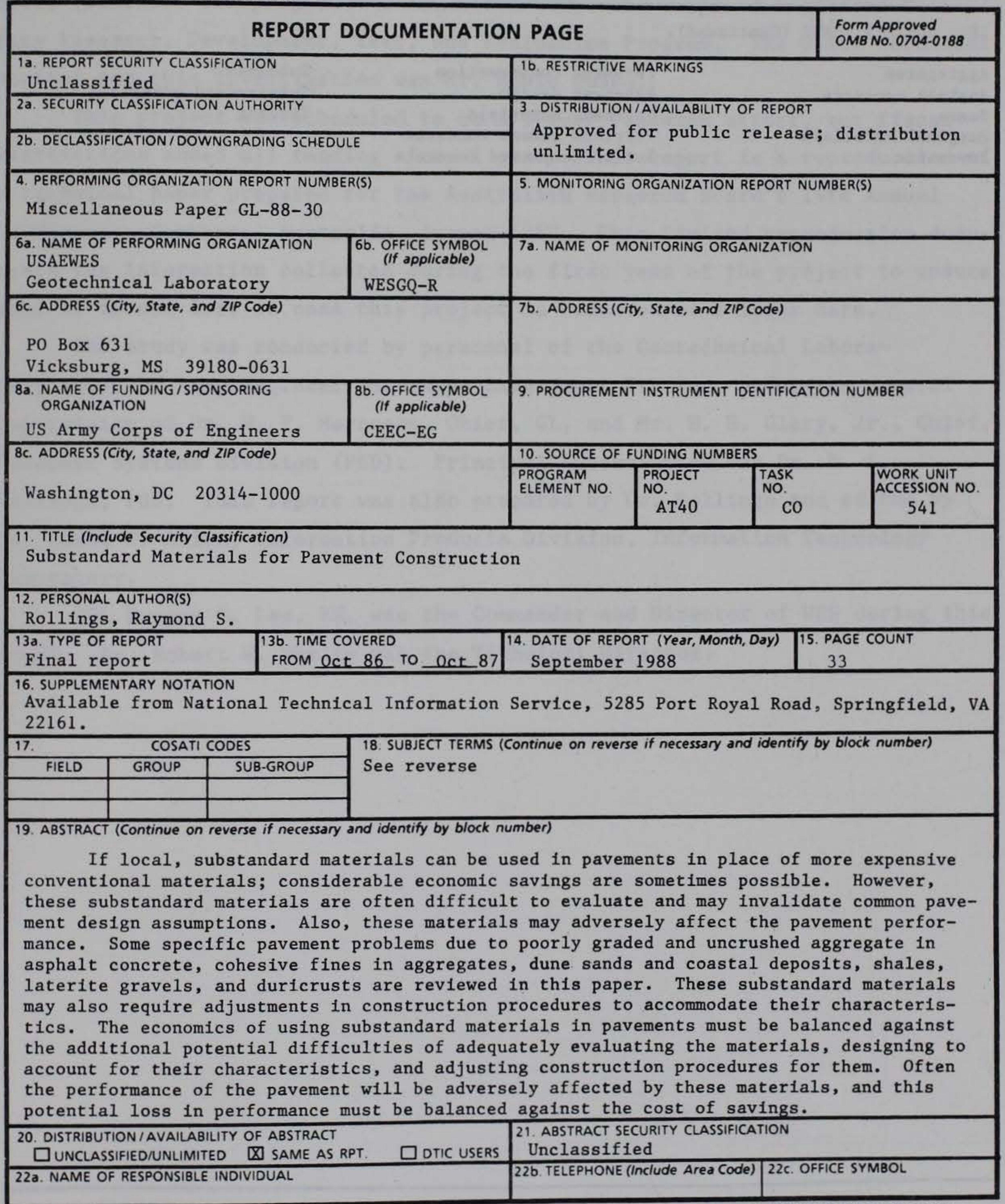

DD Form 1473, JUN 86

Previous editions are obsolete.

SECURITY CLASSIFICATION OF THIS PAGE

Unclassified 
Unclassified

IRCURITY CLASSIFICATION OF TMIS PAOE

18. SUBJECT TERMS (Continued).

Aggregates

Asphalt concrete

Bases

Marginal materials

Pavements
Pavement construction

Pavement design

Pavement materials

Portland cement concrete

Roller-compacted concrete
Subbases

Substandard materials

Testing 


\section{Preface}

This investigation was sponsored by the US Army Corps of Engineers (USACE). The project was conducted under the Corps of Engineers Military Research, Development, Test, and Evaluation Program. The USACE Technical Monitor for this investigation was Mr. Edwin Dudka.

This project was scheduled to be a 5-year research effort, but fiscal restrictions ended all funding after 1 year. This report is a reproduction of a technical paper prepared for the Australian Research Board's 14th Annual Conference, Canberra, Australia, August 1988. This limited reproduction documents the information collected during the first year of the project to ensure that it is not lost in case this project is refunded at a later date.

The study was conducted by personnel of the Geotechnical Laboratory (GL), US Army Engineer Waterways Experiment Station, under the genera1 supervision of Dr. W. F. Marcuson, Chief, GL, and Mr. H. H. Ulery, Jr., Chief, Pavement Systems Division (PSD). Principal Investigator was Dr. R. S. Rollings, PSD. This report was also prepared by $\mathrm{Dr}$. Rollings and edited by Ms. Odell F. Allen, Information Products Division, Information Technology Laboratory.

COL Dwayne G. Lee, EN, was the Commander and Director of WES during this study. Dr. Robert $\mathrm{W}$. Whalin was the Technical Director. 


\section{Contents}

$\underline{\text { Page }}$

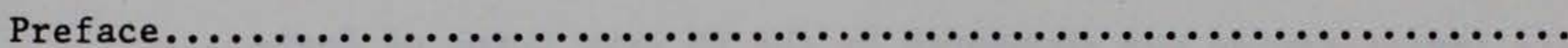

Conversion Factors, Non-SI to SI (metric)

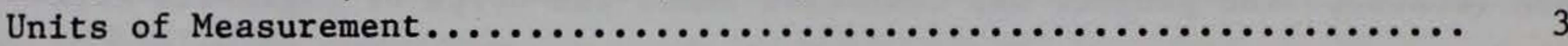

Introduction....................................... 4

Evaluation Tests.................................... 4

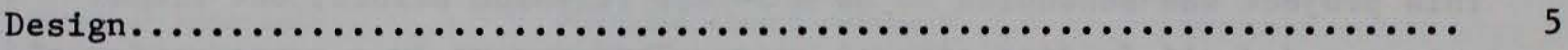

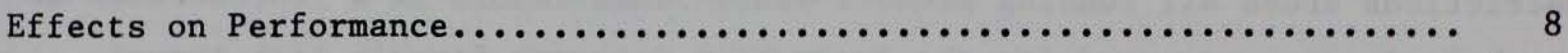

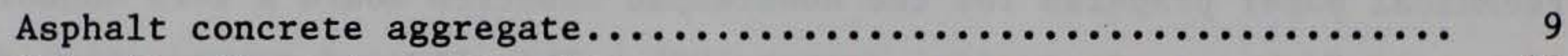

Cohesive fines in aggregates............................. 12

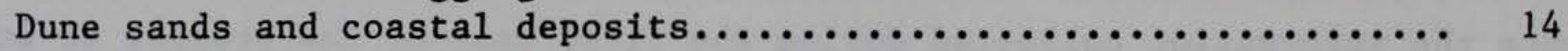

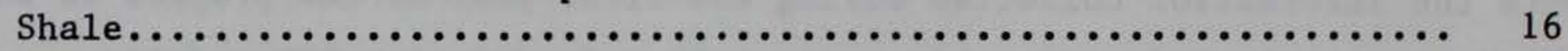

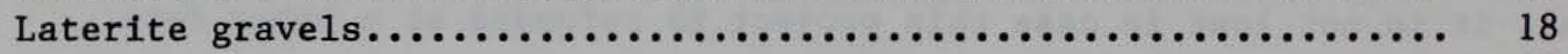

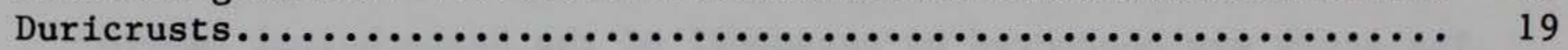

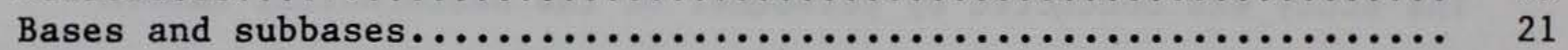

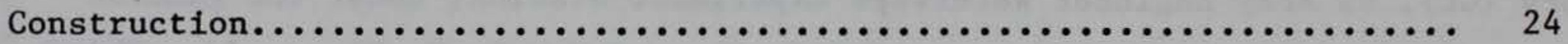

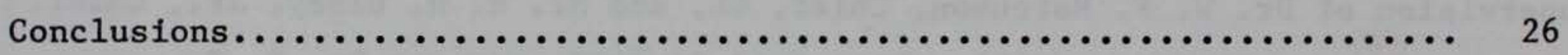

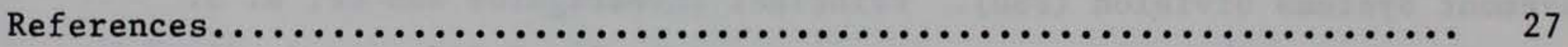




\section{Conversion Factors, Non-SI to SI (metric) Units of Measurement}

Non-SI units of measurement used in this report can be converted to SI (metric) units as follows:

\begin{tabular}{|c|c|c|}
\hline Multiply & By & To Obtain \\
\hline Fahrenheit degrees & $5 / 9$ & Celsius degrees or Kelvins* \\
\hline inches & 2.54 & centimetres \\
\hline pounds (force) & 4.448222 & newtons \\
\hline pounds (force) per square inch & 6.894757 & kilopascals \\
\hline pounds (mass) & 0.4535924 & kilograms \\
\hline pounds (mass) per cubic yard & 0.5932764 & kilograms per cubic metre \\
\hline
\end{tabular}

* To obtain Celsius (C) temperature readings from Fahrenheit (F) readings, use the following formula: $C=(5 / 9)(F-32)$. To obtain Kelvin (K) readings, use: $\mathrm{K}=(5 / 9)(\mathrm{F}-32)+273.15$. 


\section{$\underline{\text { Introduction }}$}

1. Often readily available construction materials do not meet conventional paving specifications. Either these substandard materials must be used in the pavement, or more expensive materials must be imported at considerable additional cost. The temptation to use the local materials can be overwhelming, but the decision to use or reject these materials should only be made after a thorough engineering evaluation. This evaluation must determine the engineering characteristics of the materials and must establish how they will affect the design, performance, and construction of the pavement. Unless potential problems are clearly identified, any economic savings from using the cheaper substandard materials may prove illusory.

\section{$\underline{\text { Evaluation Tests }}$}

2. The first problem encountered in evaluating substandard materials is the selection and interpretation of material tests. Often these tests and their interpretation criteria are based on experience with conventional materials and give unexpected results when used with substandard materials. The Marshall mix design method (Headquarters, Department of the Army 1987), for instance, is an effective method of proportioning dense graded asphalt concrete mixes. However, as will be discussed in later sections, it is much less effective when used with poorly graded materials, and it has a very limited ability to predict field performance. Other construction materials such as laterites or cemented materials such as duricrusts are difficult to analyze with conventional tests.

3. Undue reliance on a test of limited validity is another problem. The sulfate soundness test as discussed in American Society for Testing and Material (ASTM) ASTM C 88-76 (ASTM 1976) is widely included in many specifications to determine the resistance of aggregates to freezing and thawing. Conceptually, the growth of sulfate crystals in the aggregate capillaries because of repeated wetting and drying with sulfate solution is analogous to the growth of ice crystals in the aggregate capillaries because of repeated 
freezing and thawing. However, the real situation of an aggregate embedded within the matrix of a concrete is more complex. It has been established that the sulfate soundness test cannot clearly discriminate between aggregates that are susceptible to freezing and thawing and those that are not (Dolar-Mantuani 1978). If an aggregate passes the test, it is acceptable, but if it fails the test, it may or may not give satisfactory performance. Additional testing such as the rapid freezing and thawing test in ASTM C 666-80 (ASTM 1980) or the dilation test in ASTM C 682-75 (ASTM 1980) is appropriate before the aggregate is rejected. Blind reliance on the results of a single test may lead to a failure to recognize the true performance of a material.

4. Conventional tests on substandard materials may not give adequate indications of a material's performance. Also, acceptance criteria based on test results of conventional materials may not be suitable. Evaluation of substandard materials is appreciably more difficult than working with conventional materials, but reliable information is needed on the material's engineering characteristics to allow proper design of the pavement.

\section{Design}

5. All pavement design methods including the most sophisticated mechanistic methods rely heavily on past pavement experience and performance to establish limiting design criteria. If new materials are used in the pavement, the past experience may be misleading or simply not applicable. Also, many published design aids may include inherent assumptions concerning material properties that are not met when substandard materials are used. Consequently, the effects of using substandard materials on the design assumptions and procedures must be established.

6. Most design methods select the thickness of a concrete pavement by calculating load induced tensile stresses using some analytical model. Then these stresses and the concrete flexural strength are used to predict traffic repetitions to failure with a fatigue relationship (Rollings 1988). Often government agencies, trade associations, or individuals will assume a typical value for parameters such as concrete modulus of elasticity and publish figures or charts that provide the required thickness of pavement if the subgrade support, concrete flexural strength, and design traffic level are known. Since the aggregate properties greatly influence the modulus of elasticity of 
portland cement concrete, some concretes made with marginal materials have a significantly lower modulus than conventional concretes. If one of these published design aids is used to determine a thickness for such marginal material concrete, the differences in values between assumed and actual moduli will result in a faulty design.

7. Table 1 shows the characteristics of several aggregates studied by Chang, Hicks, and Vinson (1982). The Oceanlake basalt is a high quality aggregate, and the other basalt is subject to severe degradation in the presence of water. The Tysee sandstone is a weak, interbedded sandstone and siltstone that is susceptible to mechanical degradation. The dredged sand is a fine uniform sand. Although the study by Chang, Hicks, and Vinson (1983) examined only cement stabilization of the aggregates in Table 1, it is obvious that with additional cement (e.g., 15 percent is common for paving quality concrete) the Oceanlake basalt could reach modulus values ( 4 to 6 million $\left.1 \mathrm{~b} / \mathrm{in}^{2}{ }^{2}\right)$ * and tensile strength (600-700 $\left.1 \mathrm{~b} / \mathrm{in} .^{2}\right)$ expected of good quality paving concrete. The Eckman Creek basalt had an identical gradation to the Oceanlake basalt but had appreciably lower modulus and strength values, particularly if the effect of wetting and drying is included. The other two aggregates are even poorer. If any of these three poor quality aggregates were used in concrete, their material properties would be sufficiently different from conventional concrete that standard design aids that include assumptions on material properties could not be used.

8. The difference between typical material properties of conventional concrete and concrete made with substandard aggregates could also introduce new modes of failure not considered in the original design method. The rigidity of conventional concrete pavement keeps the stresses and strains in the subgrade well below critical values as long as the concrete has not failed. Consequently, except for unusually thin rigid pavements such as those using prestressing or steel fiber reinforcing, the subgrade is seldom stressed near failure and is often not checked in design. If substandard aggregates are used in the concrete, the concrete modulus is reduced; the rigidity of the pavement is decreased, and stresses and strains in the subgrade are increased. It is now possible that failure in the subgrade may occur prior to the fatigue failure in the concrete.

* A table of factors for converting non-SI units of measurement to SI (metric) units is presented on page 3 . 
Table 1

Material Properties for Selected Cement Stabilized Aggregates

(After Chang, Hicks, and Vinson 1982)

\begin{tabular}{|c|c|c|c|c|c|c|c|}
\hline Aggregate & $\begin{array}{c}\text { Nominal } \\
\text { Maximum } \\
\text { Size } \\
\text { in. } \\
\end{array}$ & $\begin{array}{l}\text { Percent } \\
\text { Passing } \\
\text { No. } 200 \\
\text { Sieve } \\
0.075 \mathrm{~mm} \\
\end{array}$ & $\begin{array}{l}\text { Plas- } \\
\text { ticity } \\
\text { Index } \\
\end{array}$ & $\begin{array}{c}\text { Cement } \\
\text { Content } \\
\% \\
\end{array}$ & $\begin{array}{l}\text { Water } \\
\text { Cement } \\
\text { Ratio } \\
\end{array}$ & $\begin{array}{c}\text { Tensile } \\
\text { Strength* } \\
\text { 1b/in. }{ }^{2} \\
\end{array}$ & $\begin{array}{c}\text { Elastic } \\
\text { Modulus** } \\
\times 10^{6} \\
\text { 1b/in. } \\
\end{array}$ \\
\hline Oceanlake Marine Basalt $†$ & $1 / 2$ & 9 & 5 & 3 & 0.43 & 211 & 5.0 \\
\hline Eckman Creek Marine Basalt $†$ & $1 / 2$ & 9 & 3 & 6 & 0.43 & 191 & 3.1 \\
\hline Tyee Sandstonet & $3 / 4$ & 15 & 4 & 6 & 0.43 & 110 & 3.0 \\
\hline Dredged Spoil Sand & $3 / 4 t t$ & $1+t$ & NP & 9 & 1.00 & 138 & 1.5 \\
\hline
\end{tabular}

* 31 day moist cure.

** 90 day moist cure.

+ Crushed.

t† 62 percent passing No. 4 Sieve $(4.75 \mathrm{~mm})$. 
9. Many design methods include inherent assumptions concerning materials that may be violated if substandard materials are used. For instance, the Corps of Engineers California Bearing Ratio (CBR) flexible pavement design method includes certain minimum quality and thickness requirements for the base course depending on traffic conditions. Although the Corps of Engineers CBR flexible design method can evaluate layers of material in the subgrade and layers of select fill and subbase of varying strength, it cannot evaluate the effect of a base course that does not meet the minimum quality requirements. The design system was developed from accelerated traffic tests and field experience using only high quality base course materials and therefore cannot be extrapolated directly to other conditions. If a substandard material is to be used in the base course, either it must be stabilized to improve its quality to a level consistent with the assumptions of the design method, a different design and analysis method must be used, or at least a qualitative judgement must be made on the effect of using the substandard base material.

10. The use of substandard materials can cause several problems in design. These materials may not meet assumptions used to develop published design aids. Therefore, the basis and assumptions of all design aids must be checked before they are used with substandard materials. Also, the characteristics of the substandard materials may introduce new failure modes not considered in conventional design. Finally, many design methods are based on the past performance of specific materials, and introducing different materials may invalidate the design method. The design must evaluate the effect of using a substandard material for the specific loads and climatic conditions of the project.

\section{Effects on Performance}

11. Conventional specifications for paving materials attempt to ensure that the final pavement has the strength, durability, and performance characteristics required. If substandard materials that do not meet these specifications are substituted in the pavement, some loss in pavement performance should be expected. However, depending on the intended use of the pavement, this loss in performance may be acceptable or it may be possible through proper design, proportioning, or construction to mitigate these adverse effects. Also, improvements of the substandard materials by screening to 
remove undesirable sized materials, washing to remove fines, or log washers to remove clay balls, coatings and unsound material should be evaluated. The following sections examine some problems of using several specific substandard materials in pavements.

Asphalt concrete aggregate

12. Conventional asphalt concrete used as a wearing and nominal waterproofing or water resistant surface for flexible pavements must be stable under traffic loads and environmental conditions and must protect the underlying pavement layers. Asphalt concrete stability is provided by the internal friction of the aggregate and the cohesion of the asphalt when they are blended together. Consequently, asphalt concrete aggregates are normally required to be well graded and crushed to achieve maximum internal friction. If the voids in the aggregate are not sufficiently filled with asphalt, the asphalt concrete durability suffers. If the voids in the aggregate are filled with too much asphalt, bleeding of asphalt and low stability of the asphalt concrete results.

13. Figure 1 shows several uncrushed, poorly graded aggregates studied by Grau (1979) as potential aggregates for asphalt concrete. Laboratory tests and traffic tests with up to 8,900 passes of a 40,920 to $48,6951 \mathrm{~b}$ dual wheel, tandem-axle truck found that the best performance of these materials under traffic was at asphalt cement contents below the optimum value predicted by

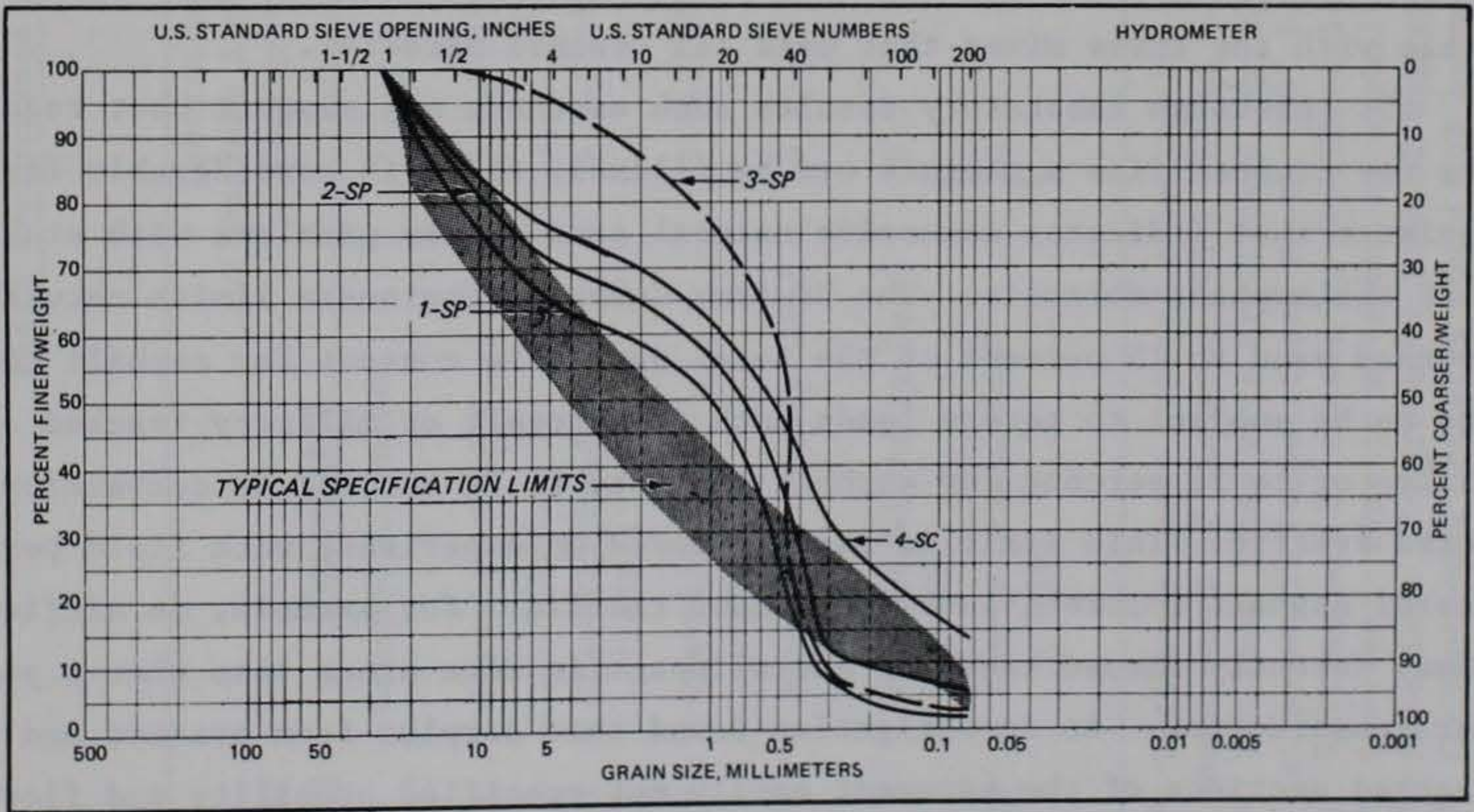

Figure 1. Marginal aggregates studied by Grau (1979) 
the conventional laboratory Marshall mix design method. The field performance of these test items is summarized in Table 2. At lower than laboratory optimum asphalt cement contents the gravelly sand, 1-SP3 in Figure 1, had rutting characteristics similar to a conventional, well-graded, crushed limestone control section but did have some raveling problems and low skid resistance during wet weather. The finer blended gravelly sand, denoted as 2-SP, had similar characteristics along with some slight shoving problems at trafficking pavement temperatures in the range of 40 to $80^{\circ} \mathrm{F}$. At higher temperatures rutting and shoving became much worse. The poorly graded sand (3-SP) rutted and shoved badly under all conditions. Although performance under traffic was improved by using asphalt contents below the laboratory optimums, the long term environmental durability of the asphalt concrete would be decreased because of high volume of unfilled voids in the asphalt concrete.

14. Considerable savings are possible if properly graded natural materials can be used without crushing. Table 3 shows some laboratory results by Bahgat and Refaey (1986) examining the relative effect of using crushed and uncrushed coarse and fine aggregate in asphalt concrete. Each asphalt concrete in Table 3 used the same aggregate gradation which met a standard gradation recommended by the US Asphalt Institute. A large loss in stability occurred when natural gravel and sand were used together, but stability increased significantly when a crushed sand was used with the natural gravel. The laboratory stability of a crushed dolomite with a natural sand was comparable with the three mixes that used all crushed material.

15. Although laboratory results such as these may suggest that requirements for crushed fine aggregate can be relaxed, there is considerable field experience that indicates excessive natural sand causes problems with stability of the asphalt concrete. The US Army Corps of Engineers limits natural uncrushed sand to 15 percent of the total aggregate content for asphalt concrete to be subject to severe loads such as aircraft or military tracked vehicles or to 25 percent for asphalt concrete to be subject to conventional wheeled traffic. This limit is largely based on experience with field performance of asphalt concrete pavements under traffic. For example, an airfield taxiway recently showed cracking and slippage in some areas less than a year after construction. An investigation found that samples from cracked and uncracked sections of the pavement easily met specified stability and flow requirements but were slightly out of specification for voids, voids filled, 
Table 2

Field Performance of Poorly Graded Aggregates Under Traffic

(After Grau 1979)

\begin{tabular}{|c|c|c|c|c|c|c|c|}
\hline $\begin{array}{l}\text { Test } \\
\text { Item }\end{array}$ & Aggregates & $\begin{array}{c}\text { Laboratory } \\
\text { Optimum Asphalt } \\
\text { Content* } \\
\% \\
\end{array}$ & $\begin{array}{c}\text { Pavement } \\
\text { Temperature** } \\
\end{array}$ & $\begin{array}{c}\text { Field } \\
\text { Asphalt } \\
\text { Content } \\
\% \\
\end{array}$ & $\begin{array}{l}\text { Maximum } \\
\text { Rutting }{ }^{-} \\
\text {in. } \\
\end{array}$ & Shoving t+ & Raveling ${ }^{\ddagger}$ \\
\hline 1 & Crushed Limestone & 5.7 & $\begin{array}{l}\text { Average } \\
\text { Hot }\end{array}$ & $\begin{array}{l}5.8 \\
5.8\end{array}$ & $\begin{array}{l}1 / 4 \\
1 / 4\end{array}$ & $\begin{array}{l}\text { none } \\
\text { none }\end{array}$ & $\begin{array}{l}\text { none } \\
\text { none }\end{array}$ \\
\hline 2 & $\begin{array}{l}\text { Grave11y Sand } \\
\text { (1-SP3) }\end{array}$ & $5.0-7.5 \neq \neq$ & $\begin{array}{l}\text { Average } \\
\text { Hot }\end{array}$ & $\begin{array}{l}7.6 \\
7.6\end{array}$ & $\begin{array}{l}3 / 8 \\
1 / 4\end{array}$ & $\begin{array}{l}\text { slight } \\
\text { slight }\end{array}$ & $\begin{array}{l}\text { none } \\
\text { none }\end{array}$ \\
\hline 3 & $\begin{array}{l}\text { Grave11y Sand } \\
\qquad(1-\mathrm{SP} 3)\end{array}$ & $5.0-7.5$ 护 & $\begin{array}{l}\text { Average } \\
\text { Hot }\end{array}$ & $\begin{array}{l}6.7 \\
6.7\end{array}$ & $\begin{array}{l}1 / 4 \\
1 / 4\end{array}$ & $\begin{array}{l}\text { none } \\
\text { none }\end{array}$ & $\begin{array}{l}\text { slight } \\
\text { none }\end{array}$ \\
\hline 4 & $\begin{array}{l}\text { Grave11y Sand } \\
\text { (1-SP3) }\end{array}$ & $5.0-7.5 \neq \neq$ & $\begin{array}{l}\text { Average } \\
\text { Hot }\end{array}$ & $\begin{array}{l}5.4 \\
5.4\end{array}$ & $\begin{array}{l}1 / 4 \\
1 / 4\end{array}$ & $\begin{array}{l}\text { none } \\
\text { none }\end{array}$ & $\begin{array}{l}\text { slight } \\
\text { none }\end{array}$ \\
\hline 8 & $\begin{array}{l}\text { Blended Gravelly Sand } \\
(2-\mathrm{SP})\end{array}$ & 6.5 & $\begin{array}{l}\text { Average } \\
\text { Hot }\end{array}$ & $\begin{array}{l}6.2 \\
6.2\end{array}$ & $\begin{array}{r}1 / 4 \\
1-1 / 2\end{array}$ & $\begin{array}{l}\text { slight } \\
\text { moderate }\end{array}$ & $\begin{array}{l}\text { none } \\
\text { none }\end{array}$ \\
\hline 9 & $\begin{array}{l}\text { Blended Gravelly Sand } \\
(2-S P)\end{array}$ & 6.5 & $\begin{array}{l}\text { Average } \\
\text { Hot }\end{array}$ & $\begin{array}{l}5.6 \\
5.6\end{array}$ & $\begin{array}{l}1 / 4 \\
3 / 4\end{array}$ & $\begin{array}{l}\text { slight } \\
\text { moderate }\end{array}$ & $\begin{array}{l}\text { none } \\
\text { none }\end{array}$ \\
\hline 10 & $\begin{array}{l}\text { Poorly Graded Sand } \\
(3-\mathrm{SP})\end{array}$ & 10.0 & $\begin{array}{l}\text { Average } \\
\text { Hot }\end{array}$ & $\begin{array}{l}6.4 \\
6.4\end{array}$ & $\begin{array}{l}1- \\
1-7 / 8\end{array}$ & $\begin{array}{l}\text { moderate } \\
\text { moderate }\end{array}$ & $\begin{array}{l}\text { none } \\
\text { none }\end{array}$ \\
\hline
\end{tabular}

* Optimum asphalt content selected by conventional 50-blow Marshall Mix Design Method (Headquarters, Department of the Army 1987) unless otherwise noted.

** Two test lanes were trafficked for each item; one at pavement temperatures 40 to $80^{\circ} \mathrm{F}$ and the other at pavement temperatures 80 to $130^{\circ} \mathrm{F}$.

+ Rutting may be caused by densification of asphalt concrete, shoving, or a combination of these.

t† Shoving: Plastic movement of asphalt concrete under traffic caused by low stability.

\# Raveling: Progressive loss of aggregate from the asphalt concrete.

㭋 Conventional criteria could not be met; 7.5 percent meets criteria for percent voids filled; 6.4 percent is average of asphalt contents to provide maximum Marshall stability and unit weight, and 5.0 percent provides a 6 micron film coating on particles. 
Table 3

Effect of Crushed Aggregate on Marshall Stability

(After Bahgat and Refaey 1986)

\begin{tabular}{|c|c|c|c|}
\hline Coarse Aggregate & $\begin{array}{l}\text { Angularity } \\
\text { Index* }\end{array}$ & Fine Aggregate & $\begin{array}{c}\text { Marshall } \\
\text { Stability** } \\
\text { lb } \\
\end{array}$ \\
\hline Natural Gravel & 63.8 & Natural Sand & 1,460 \\
\hline Natural Gravel & 63.8 & Crushed Dolomite & 1,940 \\
\hline Crushed Dolomite & 100.0 & Natural Sand & 2,420 \\
\hline Crushed Dolomite & 100.0 & Crushed Dolomite & 2,450 \\
\hline Crushed Limestone & - & Crushed Limestone & 2,420 \\
\hline Crushed Basalt & -- & Crushed Basalt & 2,600 \\
\hline
\end{tabular}

* Angularity Index is percent of sample aggregate $1 / 4 \mathrm{in}$. or greater in size with at least two "sharp" edges.

** At optimum asphalt content for each individual mix, ASTM D-1559-82 (ASTM 1982) test procedures.

and compaction. The primary difference in the two areas lay in the content of natural sand. The cracked section had a natural sand content of 33 percent, 18 percent above the specification limit of 15 percent. The uncracked section had a natural sand content of 23 percent, 8 percent out of specification. Laboratory tests such as those used by Bahgat and Refaey (1986) or used in the above failure investigation often do a poor job of analyzing unconventional materials or predicting field performance. Consequently, field trials are generally advisable before major changes in specifications or before fullscale applications of laboratory results are tried.

Cohesive fines in aggregates

16. Fine silt and clay sized particles are usually strictly limited in conventional asphalt and portland cement concrete aggregates to avoid construction, durability, and stability problems. The large surface area of the fines requires an increase in binder content, and extra effort is required to process the material before mixing to ensure that all dried clods are broken up and that the moisture content of the fine material is not excessive.

17. Hague (1981) studied the effect of plastic fines on the strength of zero slump concrete. Five mixtures were proportioned to provide a zero slump concrete with a constant aggregate to cement ratio of 6.0 . The first mixture 
was a conventional paving mixture using a crushed gravel and river sand. The second mixture substituted a fine, silty sand for the river sand. The final three mixes included additions of 1,5 , and 10 percent kaolin clay to the crushed gravel and fine, silty sand. The kaolin had a plasticity index of 49 percent. Table 4 shows that increasing fines content has a strong detrimental effect on strength. The fines increase the water demand of the mix, and the water-cement ratio increases. The addition of plastic fines is particularly damaging as can be seen by the $1,000 \mathrm{lb} / \mathrm{in} .{ }^{2}$ drop in compressive strength when 1 percent kaolin clay was added to the fine, silty sand mix.

Table 4

Effect of Increasing Fines Content on Strength of Zero Slump Concrete (Hague 1981)

\begin{tabular}{|c|c|c|c|c|}
\hline Mixture & $\begin{array}{c}\text { Percent } \\
\text { Passing } \\
\text { No. } 200 \\
\text { Sieve } \\
\end{array}$ & $\begin{array}{l}\text { Cement } \\
\text { Content } \\
1 \mathrm{~b} / \mathrm{yd}^{3} \\
\end{array}$ & $\begin{array}{l}\text { Water/ } \\
\text { Cement } \\
\text { Ratio } \\
\end{array}$ & $\begin{array}{c}\text { Compressive } \\
\text { Strength* } \\
\text { 1b/in. }{ }^{2} \\
\end{array}$ \\
\hline Conventional & 0.9 & 570 & 0.40 & 5,900 \\
\hline Fine Silty Sand & 5.6 & 539 & 0.54 & 5,200 \\
\hline 1 Percent Clay & 6.6 & 539 & 0.55 & 4,200 \\
\hline 5 Percent Clay & 10.4 & 522 & 0.61 & 3,200 \\
\hline 10 Percent Clay & 15.0 & 475 & 0.90 & 1,700 \\
\hline
\end{tabular}

* 28-day moist cure.

18. Grau (1979) examined the gravelly clayey sand marked 4-SC in Figure 1 as a potential asphalt and portland cement concrete aggregate. Laboratory tests found that at an asphalt content of 9 percent, it could meet conventional laboratory Marshall mix design criteria. Test items with asphalt contents of 4.3 to 5.5 percent performed very poorly with raveling reaching depths of 1 to $2 \mathrm{in}$. under the test truck traffic. A test section with 6.7 percent asphalt performed much better with only slight raveling. During wet weather the pavement surface was slippery. As with Grau's gravelly sand discussed in a previous section, raveling for all items was worse during wet weather.

19. This gravelly clayey sand was also mixed with $5171 \mathrm{~b} / \mathrm{yd}^{3}$ of portland cement at a water cement ratio of 0.57 to produce a zero slump concrete 
with a 28-day flexural strength of $125 \mathrm{1b} / \mathrm{in} .^{2}$. Under 11,906 passes of truck traffic with weights of 40,920 to $48,695 \mathrm{lb}$ this material performed well structurally, developing only one small crack and minor spalling. However, in wet weather the pavement surface was slippery.

20. Clay lenses in quarries can cause problems with clay contamination in crushed stone. Figure 2 shows clay balls in a concrete made from crushed limestone. The low density of the clay balls and the vibration to consolidate concrete result in the clay balls rising to the surface where they rapidly deteriorate. A similar problem occurs if aggregate with clay balls is used in asphalt concrete. This problem can usually be solved by selective quarrying and crusher adjustments.

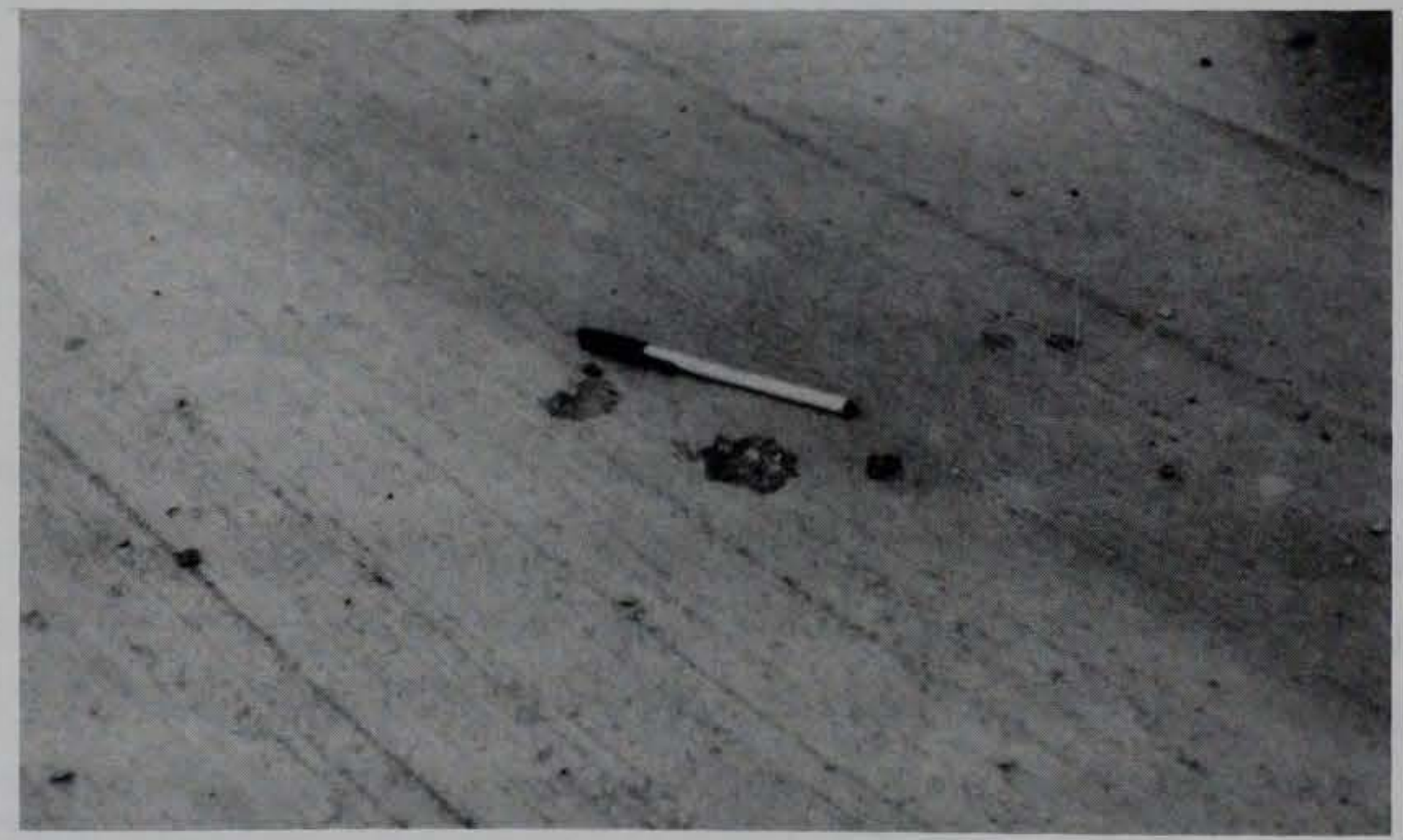

Figure 2. Deterioration of clay balls in concrete

\section{Dune sands and coastal deposits}

21. Natural beach and eolian sands such as those in Figure 3 pose problems in coastal and some desert regions. Very fine uniform sands such as the Florida dune sands are unstable under traffic. Before any construction is possible they must be stabilized. In Florida coastal regions these sands are often mixed with 40 to 60 percent by weight of dredged oyster shell to provide a stable construction platform to serve as an unsurfaced road or to provide a low quality flexible pavement base course with a CBR of approximately 50 percent. Poorly graded eolian sands have also been stabilized with asphalt emulsions (Little, Button, and Epps 1982; Evans and Hicks 1982). These mixes tend 


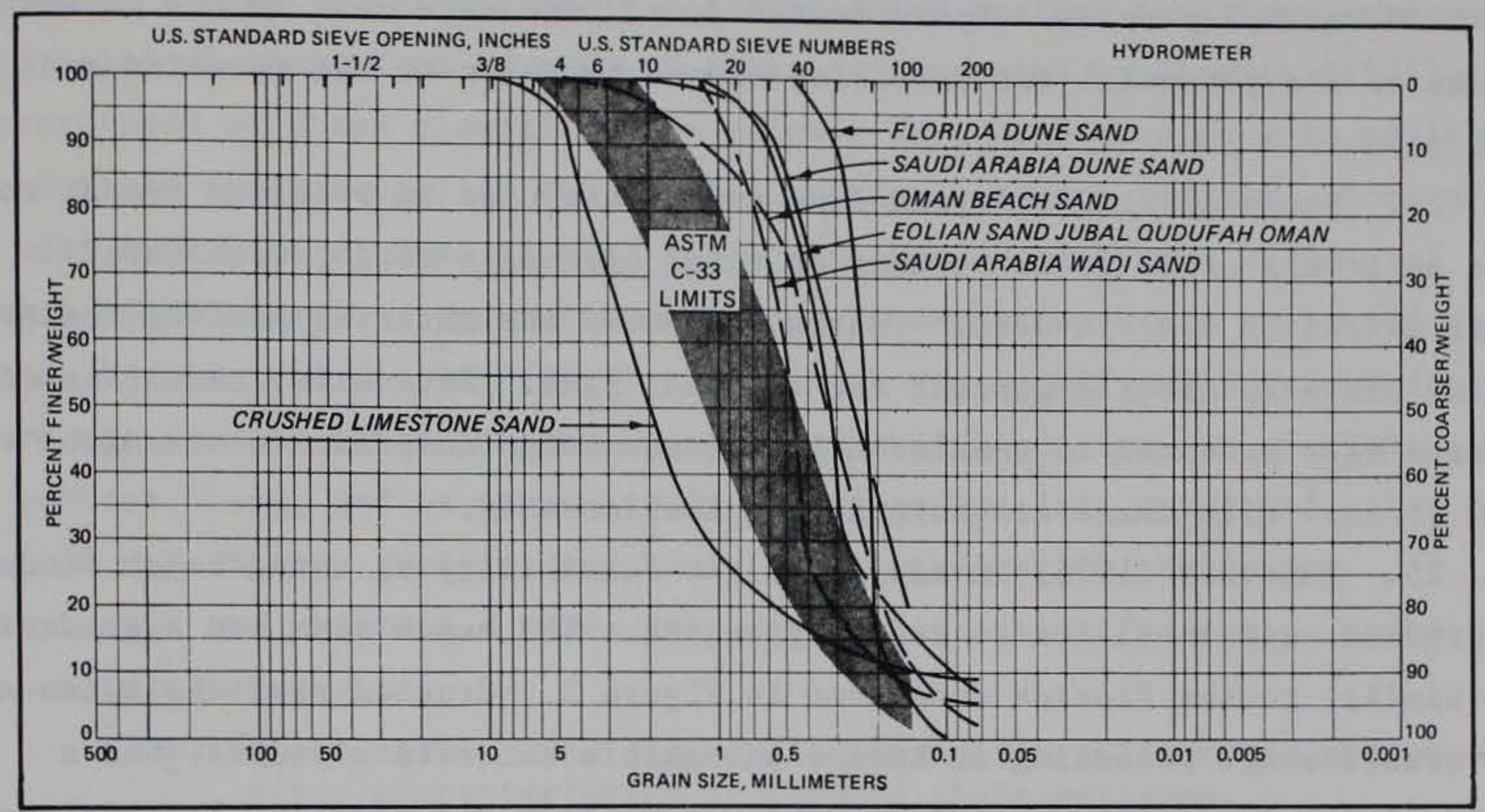

Figure 3. Fine uniformly graded sands from desert and coastal areas to have a high proportion of voids with a high moisture pickup, but resilient modulus values were acceptable.

22. Sands produced by crushing quarried stone such as the crushed sand in Figure 3 are often deficient in 50 to 100 sieve sized material. This particular crushed sand was to be used with a 3/4-in. maximum size crushed coarse aggregate in an asphalt concrete to be subject to high tire pressures. For this type of mix not more than 15 percent of the total aggregate can be natural sands because the rounded natural sand grains significantly reduce stability. In this case blending the relatively fine locally available Oman beach sands and Jubal Qudufah eolian sands with the crushed sand and coarse aggregate improved overall workability, reduced stiffness of the mix, and helped provide the 50 to 100 sieve size fractions missing from the crushed sand.

23. The natural sands in Figure 3 are much finer than normally permitted by standards for portland cement concrete aggregate as stated in ASTM C-33-82 (ASTM 1982). Nevertheless all of the natural sands in Figure 3 except the Jubal Qudufah eolian sand were used successfully in concrete. The Oman beach sand was used in a mixture of 66 percent $3 / 4-i n$. maximum nominal size crushed limestone coarse aggregate and 34 percent beach sand by total weight of aggregate. Portland cement content was $4921 \mathrm{~b} / \mathrm{yd}^{3}$. Seawater was used as mixing water, and the water-cement ratio was 0.49 . The mean 90 day flexural strength of the Oman concrete was $675 \mathrm{lb} / \mathrm{in} .^{2}$, and the coefficient of 
variation was 9.7 percent. Epoxy coated dowel bars were used in the pavement because of the potential for corrosion caused by salts in the seawater and beach sand.

24. Saudi Arabian wadi and dune sands were used in portland cement concrete at levels of 29 to 32 percent of total aggregate weight with water cement ratios of 0.47 to 0.51 * Washing reduced the material passing the number 200 sieve to about 2 percent for the Wadi Sand. Extensive quantities of concrete were produced to consistently exceed design compressive strengths of 4,000 $\mathrm{lb} / \mathrm{in} .^{2}$ with these economically available sands.

25. Popovics (1975) investigated the feasibility of using beach sands and crushed reef shell for concrete aggregate. The beach sand had a gradation very similar to the Florida dune sand in Figure 3. Crushed reef shell has an unfavorable shape resulting in harsh, unworkable concrete mixtures, has a relatively low specific gravity, and has absorption and abrasion loss values higher than conventional coarse aggregates. A mixture with adequate workability could be obtained with 60 percent crushed reef she11, 40 percent beach sand, $564 \mathrm{lb} / \mathrm{yd}^{3}$ cement, and suitable amounts of $\mathrm{fly}$ ash and air entraining admixture. A water cement ratio of 0.75 with this proportioning could obtain $550 \mathrm{lb} / \mathrm{in} .^{2}$ flexural strength at 28 days but only $2,500 \mathrm{lb} / \mathrm{in} .^{2}$ compressive strength. The modulus of elasticity of reef shell and beach sand concrete was much lower than conventional concrete. The low compressive strength of concretes made with reef shell and beach sand suggests that they would abrade badly if subjected to traffic. Consequently, their greatest potential application may be as a stabilized base with a thin surfacing of asphalt concrete to serve as a wearing course.

Shale

26. Shale is a widely distributed material varying from soft clay shales to tough, calcareous or silica cemented shales. Many unsatisfactory experiences with shales in construction have led to their general exclusion from many construction specifications. Nevertheless, some shales are suitable for construction; others are not. Unfortunately, there are no accepted criteria to reliably separate one type of shale from the other.

* Data on the Saudi Arabian wadi and dune sands and their use in concrete were provided courtesy of Mr. W. Voelker, Chief Foundations and Materials, Middle Eastern and African Project Office, US Army Corps of Engineers, Winchester, VA. 
27. A wide variety of shale classification systems have been proposed, and a critical comparison of some of these is presented by Chapman (1975). However, none of these classification schemes have been coupled with monitoring of field performance; so their value remains somewhat limited. Some of the most extensive studies of clay shale were sponsored by the US Federal Highway Administration, and recommendations from this work are presented by Strohm, Braggs, and Ziegler (1978). This work was specifically oriented toward use of clay shale in embankments, and guidelines for use of shales in the subbase, base, and as aggregate in pavements are less developed.

28. Reidenour, Geiger, and Howe (1976) studied 224 shales in Pennsylvania and proposed a three step method for evaluating shale durability for use in pavements:

a. Field survey examining shale lamination thicknesses and weathering characteristics of exposed shale outcrops.

b. Laboratory screening test by soaking shale samples in ethylene glycol for $40 \mathrm{hr}$.

c. Modified Washington degradation test which is based on physical degradation of sample in water when placed on sieve shaker for 20 min.

Reidenour, Geiger, and Howe felt that a shale passing the first two screening tests and achieving a Washington degradation factor of 45 or more might be suitable for asphalt or concrete aggregate. With a degradation factor greater than 20 the shale should be suitable for base and granular fill material.

29. This evaluation procedure offers a reasonable approach to evaluating shales for use in pavement construction. However, monitoring of field performance is needed to confirm or adjust the tentative degradation factors. Also, this work covered only shales from a limited area, and shales in other areas may require some modifications to these tests. For instance, the ethylene glycol used in the screening test reacts with montmorillonite clays resulting in rapid expansion and breakdown of shales containing this clay mineral. This clay mineral is associated with poor durability. However, Chapman (1975) found that three nondurable Indiana shales showed less slaking with the ethylene glycol than with water because of the shale's lack of montmorillonite. Consequently, he concluded that the ethylene glycol test was of little value for his specific shales. Noble (1977) soaked shales in sulfuric acid and used the acid's reaction with chlorite in shales to differentiate between durable and nondurable Virginia shales. Investigators in different areas have 
found different slake durability tests to be appropriate. Similarly, other investigators have reported success with other degradation tests besides the Washington degradation test.

30. Although some local modifications to the specific tests may be needed or desired, the framework for shale evaluation proposed by Reidenour, Geiger, and Howe (1976) is very promising. The field evaluation of the weathering characteristics and some initial slaking durability test should identify clearly unsuitable shales. Then a physical degradation test such as the Washington degradation test should further differentiate the mechanical strength and durability of the shales and identify their potential applications in pavement construction. The critical information that is still missing from this and all similar rating schemes is a direct correlation between the classification and actual field performance.

31. When nondurable shales are used as fill or embankment material to form the pavement subgrade, selection of a design CBR for these materials is difficult. Smith (1986) evaluated several proposed methods of determining the design CBR of clay shales. However, the different methods gave erratic results, and he recommended selecting the design $C B R$ on the basis of the $C B R$ of overlying clay weathered from the shale. Since this clay represents the final condition of weathering for the shale, it is probably the best indicator of the final, lowest strength the shale will eventually reach.

\section{Laterite gravels}

32. Tropical areas often have extensive laterite deposits, and specifications developed in temperate climates of ten do a poor job of evaluating the engineering properties of these materials. Laterite gravels show a wide variety of properties. Testing of 35 laterite gravels from six countries by Krinitzsky, Patrick, and Townsend (1976) found that they consisted of 11 to 92 percent gravel size or larger particles (number 4 or larger sieve), 2 to 31 percent passing the number 200 sieve, plasticity indexes of 0 to 30 percent, and Los Angeles Abrasion test results of 4 to 38 percent. A number of these samples showed sufficient gravel quantities, plasticity characteristics, and abrasion resistance to suggest that they could be used as asphalt concrete aggregate if properly crushed and processed.

33. Swartzman, Sanneh, and Mason (1986) described the use of a crushed laterite aggregate for asphalt concrete in Gambia. The only economical local aggregates were a ferrigunious laterite and beach sand. The laterite 
aggregate was soft and highly absorptive contained plastic fines. It had a Los Angeles abrasion between 44 and 55 percent and plasticity index of 9 percent. Blending processed and crushed laterite aggregate with 20 percent beach sand reduced the plasticity index of the fine aggregate at the asphalt plant to 4 percent. Marshall mix design results had stabilities up to $1,0201 \mathrm{~b}$, but the mix was consistently low in air voids. Some pavements constructed with the laterite aggregate are up to 8 years old and are giving useful service despite significant aggregate wear under local traffic. Asphalt concrete made with this aggregate will not perform as well as with more expensive imported aggregate, but it is an economical alternative for this application.

Duricrusts

34. Surface hardpans, often referred to as duricrusts, are formed in many arid regions of the world. These are sometimes further identified by their major components, i.e., calcium carbonate rich crusts are termed calcretes; calcium-magnesium carbonates are dolocretes; calcium sulphates are gypcrete, and silicaceous deposits are silicretes. These deposits are highly variable and are often reactive, highly contaminated, or both. However, with selective quarrying and processing, usable, if not optimal, construction materials can be developed.

35. Figure 4 from Fookes and Higginbottom (1980a) 1llustrates the variability of a Dubai calcrete. This variability greatly complicates quarrying, and the importance of careful, selective quarrying has been widely emphasized (Carseldine and Parkinson 1986; Fookes and Higginbottom 1980a, 1980b). Chemical contaminants and plastic fines tend to concentrate in the finer fractions; consequently, the material produced from the primary and sometimes the secondary crusher may have to have fines scalped and removed to reduce overall contamination in the aggregate.

36. The potential for alkali-aggregate reactions, the common presence of chemical contaminants, and the variable quality of the various duricrusts require a good chemical and aggregate soundness evaluation program. The chemical contaminants can be controlled to some extent by the process of washing. Alkali-reactive aggregates may require low alkali cements, or the alkalisilica reaction might be controlled by additions of pozzolins such as flyash or ground slag. The effectiveness of the specific flyash and slag must be determined by testing since their effectiveness varies. Soundness is best controlled by selective quarrying and processing of the duricrusts. 


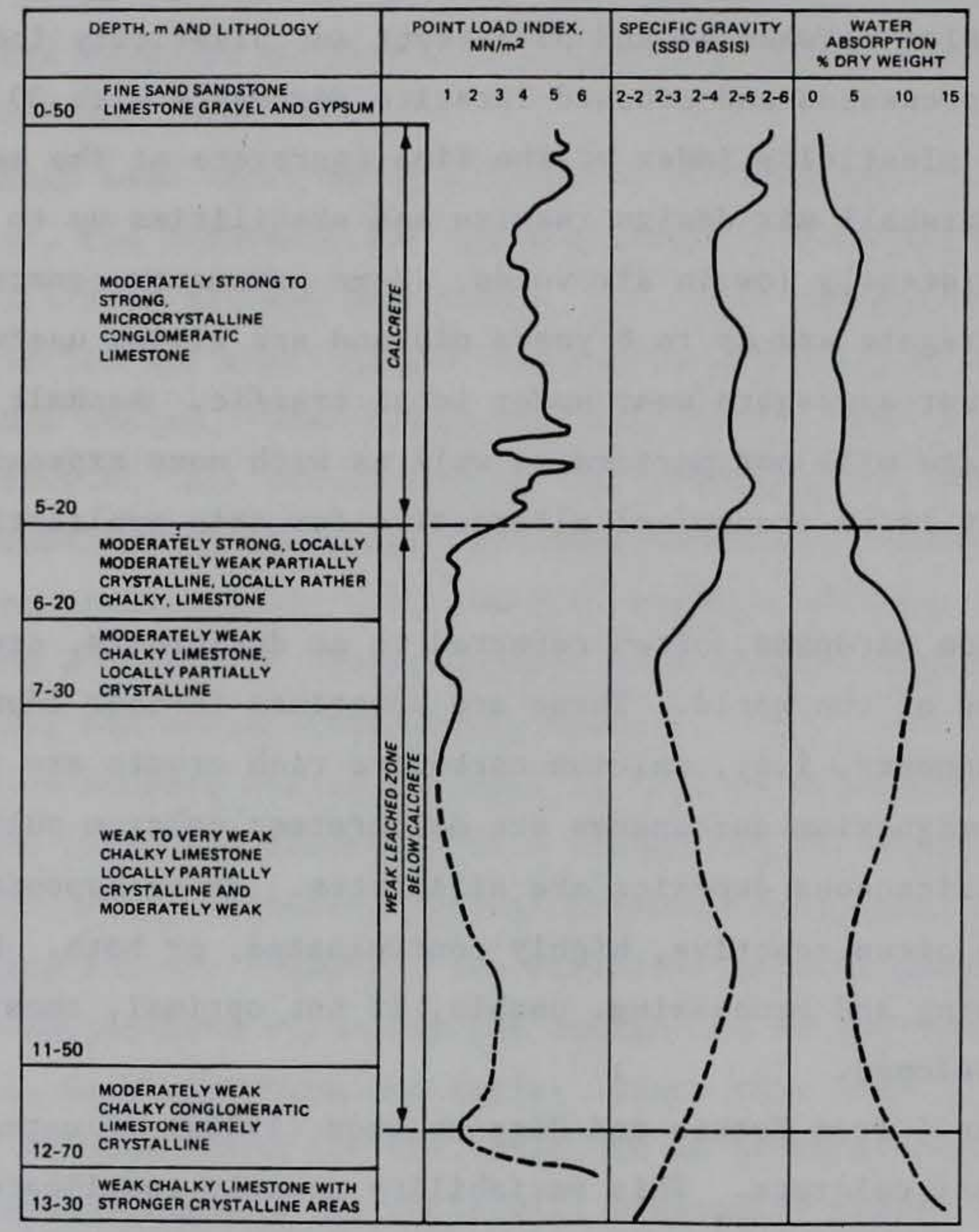

Figure 4. Variability of a Dubai calcrete deposit (Fookes and Higginbottom 1980a)

37. Despite their inherent limitations, duricrusts can, if evaluated and processed properly, be used as construction materials. Some specific examples of applications include Carseldine and Parkinson's (1986) description of silicrete used as a subbase, base, and concrete aggregate in Queensland, Australia; Struillou and Alloul's (1984) description of calcrete and gypcrete used on unsurfaced roads for light traffic in Algeria; Frydman's (1982) description of calcareous sands used as bases and subbases in Israel; and Shayan, Ritchie, and Diggins (1986) investigation of a calcrete from Victoria as a concrete aggregate. Netterberg (1982) notes that common test methods and specifications developed for conventional pavement construction materials may have limited applicability with these materials. Fookes and Higginbottom $(1980 \mathrm{a}, 1980 \mathrm{~b})$ provide a very useful description of the properties and processing required for duricrusts in the Arabian peninsula. 
Bases and subbases

38. The base and subbase (if required) for a flexible or rigid pavement provide structural support to the pavement surfacing. For flexible pavements the main load carrying structure is the base and subbase. For a rigid pavement the structural contribution of the base is less pronounced. The base and subbase can also provide a construction platform, drainage, pumping protection, frost protection, and other contributions to successful pavement performance. In order to perform these functions, the materials used in the base and subbase are generally required to meet some basic gradation requirements, Atterberg limits, and possibly other factors such as strength, durability, and minimum percent crushed particles.

39. The materials used in the base and subbase comprise a large fraction of the entire pavement volume and cost. Large potential savings are often possible if local materials not meeting conventional base and subbase requirements can be substituted for more expensive imported materials. Metcalf (1988) has recently summarized Australian base and subbase requirements and reviewed Australian experience with local materials used in base and subbase construction. Rather than review this material again, this paper will concentrate on the experience and philosophy of the US Army Corps of Engineers on base and subbase materials, examine some specific examples of problems, and briefly consider stabilization of base and subbase materials.

40. Table 5 summarizes some of the base and subbase requirements used by the Corps of Engineers. For an engineer to use the design CBR shown in Table 5 the material must meet both the specified requirements and must also exceed the design CBR when soaked and tested in the laboratory. If a material exceeds the design $C B R$ in the laboratory, it is still limited to the maximum design CBR shown in Table 5. For instance if a natural gravel has a soaked CBR of 100 in the laboratory, it can still only be considered as an 80 CBR for design.

41. If a substandard material is to be substituted for a conventional material, its impact on structural performance must be assessed. For instance, flexible pavements for military aircraft with tire pressures of $200 \mathrm{lb} / \mathrm{in} .{ }^{2}$ require a minimum $6-\mathrm{in}$.-thick crushed stone base with a minimum soaked $C B R$ of 100 under the asphalt concrete surface. Substituting a CBR 80 natural gravel for this is highly unlikely to give satisfactory results. However, under light traffic with tire pressures less than $100 \mathrm{lb} / \mathrm{in} .^{2}$ it might 
Table 5

Sample Corps of Engineers Base and Subbase Requirements

\begin{tabular}{|c|c|c|c|c|c|}
\hline \multirow[b]{2}{*}{ Material } & \multicolumn{5}{|c|}{ Maximum Allowable Value } \\
\hline & $\begin{array}{c}\text { Design } \\
\text { CBR } \\
\end{array}$ & $\begin{array}{l}\text { Percen } \\
\text { No. } 10 \\
2 \mathrm{~mm} \\
\end{array}$ & $\begin{array}{l}\text { Passing } \\
\text { No. } 200 \\
0.075 \mathrm{~mm} \\
\end{array}$ & $\begin{array}{c}\text { Liquid } \\
\text { Limit, \% }\end{array}$ & $\begin{array}{l}\text { Plasticity } \\
\text { Index, \% }\end{array}$ \\
\hline Crushed stone & 100 & * & 10 & 25 & 5 \\
\hline Coaral & 80 & * & 10 & 25 & 5 \\
\hline Natural aggregates & 80 & * & 10 & 25 & 5 \\
\hline & 50 & 50 & 15 & 25 & 5 \\
\hline & 40 & 80 & 15 & 25 & 5 \\
\hline & 30 & 100 & 15 & 25 & 5 \\
\hline & 20 & - & 25 & 35 & 12 \\
\hline
\end{tabular}

* Several acceptable gradation bands to provide well graded base course material.

be quite appropriate to substitute a CBR 50 natural gravel for the commonly specified CBR 80 gravel base. Each case has to be analyzed individually for the anticipated traffic loads, climatic influences, and potential economics.

42. One simple method of improving an inferior material is to blend it with another better material. As an example, a contractor building a military airfield planned to use a local residual gravel from gabbro as a subbase. Samples of this material in situ failed to meet the No. 200 sieve limitation 4 percent of the time and Atterberg limit requirements 19 percent of the time. By careful sampling and mapping and selective excavation the contractor anticipated meeting the project specifications. He found, however, that the material degraded when handled, and after excavation and screening to remove over size particles, the material was falling to meet the No. 200 sieve limits 47 percent of the time and the Atterberg limit requirements 62 percent of the time. Compaction further degraded the material with 58 percent of the samples failing the No. 200 sieve limits. Unfortunately, there was no other source of acceptable material available locally in sufficient volume for the project. By blending the residual aggregate with a local clean sand the contractor was able to compact the material and meet the Atterberg limit requirements, but he still failed the No. 200 sleve limit 25 percent of the time. However, since he was failing the No. 200 sieve limit by 4 percent or less, most samples were 
nonplastic, and there was no economical alternative material, the contractor was allowed to use the blend for the subbase, and the pavement has performed adequately for over 5 years.

43. Ignoring the plastic index limit is often a requested waiver for a substandard material being proposed for a base or subbase, but the plasticity characteristics are often a clue to strength loss in the presence of moisture. In Vicksburg, MS, a local clay gravel has a plasticity index of about 12 percent, well above the 5 or 6 percent used by most agencies as a maximum. When compacted to 100 percent of modified AASHTO density this material can reach a CBR of 105. As long as it can be kept dry it is an excellent material, but upon soaking the CBR falls to 62 . This is not adequate for a base under normal or heavy traffic, but it is a feasible base strength to support light load traffic. However, light load pavements seldom have the quality control, construction effort, or underlying support to obtain 100 percent modified AASHTO density in the field. The soaked CBR for this clay gravel at 95 percent density is only 13 and clearly unacceptable as a base material. Unfortunately, this particular clay gravel is appreciably cheaper than alternative base materials, and it continues to be periodically used in government, commercial, and private construction with continuing pavement failures.

44. Stabilization with lime, cement, bitumen, flyash and lime, or slag cement and lime are all potential methods of upgrading an otherwise unacceptable material. For instance, the clay gravel in the previous paragraph has been successfully stabilized with both lime and portland cement to form stabilized bases for heavy truck and aircraft size traffic loads in test sections at the US Army Engineer Waterways Experiment Station.

45. Strength is commonly emphasized by most agencies in evaluating stabilized material, but durability is no less important. The aggregates studied by Chang, Hicks, and Vinson (1982) in Table 1 and described earlier all show potential durability problems. After 12 cycles of wetting and drying the tensile strength and resilient modulus had decreased 17 and 48 percent, respectively, for the Oceanlake basalt, 16 and 62 percent for the Eckman Creek Marine basalt, 4 and 11 percent for the sandstone, and 18 and 38 percent for the dredged spoil sand. The effects of 12 cycles of freezing and thawing was generally much less severe. Although stabilization may appreciably improve the properties of the two basalts and dredged sand compared to their unstabilized properties, their modulus and strength values are likely to suffer 
significant reductions in the field because of environmental action, and these reduced values should be considered in design. The Tysee sandstone seemed to be less affected by environmental effects, but it is a very weakly cemented sandstone. Consequently, it will degrade under placement and compaction operations and the increasing fine content from this degradation will cause many construction problems.

46. Cement treated material is sometimes specified under concrete pavement to resist pumping. This unfortunately is not a panacea for the problem. California has found that cement treated bases erode under heavy truck traffic resulting in severe faulting (Ames 1985). They now substitute a lean concrete base where they previously used a cement-treated base, but precise criteria in terms of traffic climate and base requirements to resist erosion are not yet established.

47. If a stabilized material is mixed at a central plant and good placement and compaction procedures are used in the field, it may be possible to achieve strength and modulus values in the field that approach those achieved in the laboratory. If, however, as is more common, the stabilizer is mixed with the substandard material in the field, variations in depth of mixing, dispersal of stabilizer within the substandard material, amount of stabilizer, moisture content, and amount of compaction achieved will lead to a different product in the field than was designed in laboratory. In general, strength and modulus values will be lower in the fleld than in the laboratory, and suitable allowance for this should be made by the designer when evaluating the substandard material.

\section{Construction}

48. When substandard materials are used for pavements they may cause major construction problems. Grau (1979) had intended to use a clayey sand with 43 percent passing the number 200 sieve and a plasticity index of 9 as one the asphalt concrete test items in his accelerated traffic tests. Laboratory tests were successfully conducted with this material, but it proved impossible to process this clayey sand through an asphalt plant because of the quantity of fine material it contained.

49. An asphalt concrete may crack and move laterally under rollers when it is placed. This is most commonly due to high mixture temperature, poor aggregate gradation, the type of asphalt cement, or the type of aggregate 
(Brown 1984). Asphalt concrete made with substandard aggregates can be expected to exhibit this type of behavior due to poor gradation, excess fines, poor quality aggregate, or a combination of these factors. Grau (1979) had to compact some of his low stability asphalt concrete mixes at temperatures much cooler than normal. This makes it difficult to achieve acceptable levels of compaction. The Gambian lateritic asphalt concrete described by Swartzman, Sanneh, and Mason (1986) cracked badly under the steel-wheel breakdown roller. This cracking was eliminated by using a rubber-tired roller for the initial breakdown and all further rolling and discontinuing use of the steel-wheel roller.

50. The fine sands such as the beach, dune, and eolian sands discussed earlier can cause workability problems when they are used in portland cement concrete. Mixture proportioning studies must examine the interactions between strength, workability, and economics before such sands can be accepted for use. Air entraining agents were used successfully with the Oman beach sand concrete, but the Saudi Arabian dune and wadi sand concretes were excessively sticky when air entraining agents were used. Water reducing admixtures, high range water reducing admixtures, and retarders were used successfully with these mixtures.

51. When substandard aggregates with excessive fines are used in portland cement concrete, water demand is increased and construction problems can be expected. Roller compacted concrete is a technique whereby a zero slump concrete is placed with a conventional asphalt laydown machine and then compacted with heavy vibratory steel wheel and rubber-tired rollers (Pittman 1988, Rollings 1988). This type of construction has been used primarily for construction of economical, industrial pavements with conventional aggregates. However, the ability to handle zero slump concrete materials makes it a potential construction method for portland cement concrete made with substandard aggregates. The increased water demand due to excessive fines in the aggregate can be partially offset by not needing as much workability with roller compacted concrete as with conventional portland cement concrete construction. Grau (1979) used roller compacted concrete construction for the test item he built with the gravelly clayey sand concrete. Table 6 shows results by Hague and Ward (1986) of several portland cement concretes made with poor quality aggregates and proportioned for zero slump. Although roller compacted 
Table 6

Zero Slump Concrete Strengths with Marginal Aggregates

$\underline{\text { (Hague and Ward 1986) }}$

\begin{tabular}{|c|c|c|c|}
\hline \begin{tabular}{c}
\multicolumn{2}{c}{ Proportions } \\
Cement: Dune Sand: \\
Coarse Aggregate
\end{tabular} & $\begin{array}{l}\text { Water/ } \\
\text { Cement } \\
\text { Ratio } \\
\end{array}$ & $\begin{array}{l}\text { Strength } \\
\text { 1b/in. }{ }^{2} \\
\end{array}$ & $\begin{array}{l}\text { Strength } \\
1 \mathrm{~b} / \mathrm{in} .^{2}\end{array}$ \\
\hline $1: 3.8: 8.2$ Greywacke & 0.8 & 116 & 2,300 \\
\hline $1: 2.5: 5.5$ Greywacke & 0.7 & 261 & 2,680 \\
\hline $1: 3.8: 8.2$ Unweathered Shale & 0.6 & 203 & 1,349 \\
\hline $1: 2.5: 5.5$ Unweathered Shale & 0.5 & 334 & 2,465 \\
\hline
\end{tabular}

* 28-day moist cure.

construction techniques could handle the materials, a large penalty in strength must still be paid for the low quality aggregates.

\section{Conclusions}

52. Economics may require the use or at least the consideration of substandard, marginal materials for pavement construction. Use of these materials will affect design, pavement performance, and construction. Evaluation of material properties with conventional tests is often difficult, and design methods must be used that are compatible with the materials. Design must evaluate the materials for the specific loads and climatic conditions to be encountered. These materials may cause poorer performance of the pavement and often result in rutting, cracking, shoving, raveling, aggregate abrasion, popouts, low skid resistance, low strength, shortened service life, or some combination of these problems. If the loss in performance from using these marginal materials is not acceptable to the user, then any monetary savings realized by using such materials is illusory. Marginal materials may also greatly affect the workability of pavement materials, and adjustments in construction procedures may be required.

53. Use of substandard materials in pavement construction has the potential to save money; however, there will generally be some loss in performance that will have to be accepted. It is wishful thinking to expect to get something for nothing. 


\section{$\underline{\text { References }}$}

American Society for Testing and Materials. 1976. "Test Method for Soundness of Aggregates by Use of Sodium Sulfate or Magnesium Sulfate," ASTM C 88-76, Philadelphia, PA.

- 1980. "Standard Test Method for Resistance of Concrete to Rapid Freezing and Thawing," ASTM C 666-80, Philadelphia, PA.

- 1980. "Standard Recommended Practice for Evaluation of Frost Resistance of Aggregates in Air-Entrained Concrete by Critical Dilation Procedures," ASTM C 682-75 (R 1980), Philadelphia, PA.

- 1982. "Standard Test Method for Resistance to Plastic Flow of Bituminous Mixtures Using Marsha11 Apparatus," ASTM D 1559-82, Philadelphia, PA.

- 1982. "Standard Specification for Concrete Aggregates," ASTM C 33-82, Philadelphia, PA.

Ames, W. H. 1985. "Concrete Pavement Design and Rehabilitation in California," Proceedings, Third International Conference on Concrete Pavement Design and Rehabilitation, Purdue University, West Lafayette, IN.

Bahgat, A. G. and Refaey, A. H. E. 1986. "Performance of Natural Sandy Gravel Materials in Pavement Layers," 6th IRF African Highway Conference, Cairo, Egypt.

Brown, E. R. 1984. "Experiences of Corps of Engineers in Compaction of Hot Asphalt Mixes," Placement and Compaction of Asphalt Mixes, F. T. Wagner editor, STP 829, American Society for Testing and Materials, Philadelphia, PA.

Carseldine, H. B and Parkinson, B. D. 1986. "Experience with Silicrete Materials in Road Construction in Northwest Queensland," Proceedings, 13th Australian Road Research Board Conference, Adelaide, Australia.

Chang, C., Hicks, R. G., and Vinson, T. S. 1982. "Benefaction of Marginal Coastal Oregon Aggregates with Cement," Extending Aggregate Resources, STP 774, American Society for Testing and Materials, Philadelphia, PA.

Chapman, D. R. 1975. "Shale Classification Tests and Systems: A Comparative Study," Joint Highway Research Project JHRP-75-11, Purdue University, IN.

Dolar-Mantuani, L. 1978. "Soundness and Deleterious Substances," Significant of Tests and Properties of Concrete and Concrete-Making Materials, STP 169B, American Society for Testing and Materials, Philadelphia, PA.

Evans, G. L. and Hicks, R. G. 1982. "Properties of Marginal Aggregates Treated with Asphalt Emulsion," Extending Aggregate Resources, STP 774, American Society for Testing and Materials, Philadelphia, PA.

Fookes, P. G. and Higginbottom, I. E. 1980a. "Some Problems of Construction Aggregates in Desert Areas, with Particular Reference to the Arabian Peninsula, 1: Occurrence and Special Characteristics," Proceedings, The Institution of Civil Engineers, Part I, Vo1 68, United Kingdom. 
Fookes, P. G. and Higginbottom, I. E. 1980b. "Some Problems of Construction Aggregates in Desert Areas, with Particular Reference to the Arabian Peninsula, 2: Investigation, Production, and Quality Control," Proceedings, The Institution of Civil Engineers, Part I, Vo1 68, United Kingdom.

Frydman, S. 1982. "Calcareous Sands of the Israeli Coastal Plain," Geotechnical Properties, Behavior, and Performance of Calcareous Soils, K. R. Demus and R. C. Chaney editors, STP 778, American Society for Testing and Materials, Philadelphia, PA.

Grau, R. W. 1979. "Utilization of Marginal Construction Materials for LOC," Technical Report GL-79-21, US Army Engineer Waterways Experiment Station, Vicksburg, MS.

Hague, M. N. 1981. "No-Slump Concrete with Fine Sand and Clay," Cement and Concrete Research, Vol 11, No. 4., Pergamon Press Ltd.

Hague, M. N., and Ward, M. A. 1986. "Marginal Materials in Roller Compacted Concrete for Pavement Construction," Journal of the American Concrete Institute, No. 4 Proceedings Vol 83, Detroit, MI.

Headquarters, Department of the Army. 1987. "Bituminous Pavements Standard Practice," TM 5-822-8, Washington, DC.

Krinitzsky, E. L., Patrick, D. M., and Townsend, F. C. 1976. "Geology and Geotechnical Properties of Laterite Grave1," Technical Report S-76-5, US Army Engineer Waterways Experiment Station, Vicksburg, MS.

Little, D. N., Button, J. W., and Epps, J. A. 1982. "Potential for Asphalt Stabilized Sand Bases in Texas," Extending Aggregate Resources, STP 774, American Society for Testing and Materials, Philadelphia, PA.

Metcalf, J. B. 1988. "The Use of Naturally-Occurring Nonstandard Materials for Road Base Construction in Australia," Program and Papers, 26th Australian Road Research Board Regional Symposium, Bunburg, Australia.

Netterberg, F. 1982. "Geotechnical Properties and Behavior of Calcretes in South and Southwest Africa," Geotechnical Properties, Behavior, and Performance of Calcareous Soils, K. R. Demurs and R. C. Chaney editors, STP 777, American Society for Testing and Materials, Philadelphia, PA.

Noble, D. F. 1977. "Accelerated Weathering of Tough Shales, Final Report," VHTRC 78-R20, Virginia Highway and Transportation Research Council, Charlottesville, VA.

Pittman, D. W. 1988. "Construction of Roller Compacted Concrete Pavement at Kitzingen, West Germany," Proceedings, 14th Australian Road Research Board Conference, Canberra, Australia.

Popovics, S. 1975. "Reef Shell-Beach Sand Concrete," Living with Marginal Aggregates, STP 597, American Society for Testing and Materials, Philadelphia, PA.

Reidenour, D. R., Geiger, E. G., and Howe, R. H. 1976. "Suitability of Shale as a Construction Material," Living with Marginal Aggregates, STP 597, American Society for Testing and Materials, Philadelphia, PA.

Rollings, R. S. 1988. "Design and Construction of Roller-Compacted Concrete Pavements," 14th Australian Road Research Board Conference, Canberra, Australia. 
Shayan, A., Ritchie, D. F., and Diggins, R. 1986. "Evaluation of Calcrete for Use in Concrete," Proceedings, 13th Australian Road Research Board Conference, Adelaide, Australia.

Smith, R. B. 1986. "Evaluation of Sydney Shales for Use in Road Construction," Proceedings, 13th Australian Road Research Board Conference, Adelaide, Australia.

Strohm, W. E., Bragg, G. H., Ziegler, T. W. 1978. "Design and Construction of Compacted Shale Embankments; Vol 5, Technical Guidelines," FHWA-RD-78141, Federal Highway Administration, Washington, DC.

Struillou, R. and Allou1, B. 1984. "Road Upgrading of Encrusting Tufa in Algeria," International Symposium on Aggregates, International Association of Engineering Geology, Nice, France.

Swartzman, F. L., Sanneh, L. M., and Mason, W. J. 1986. "Local Laterite Aggregates in Pavement Construction," 6th IRF African Highway Conference, Cairo, Egypt. 